\title{
Contribution of Biofertiliser (Frateuria auranta) in an Integrated Potassium Management Package on Growth of Apple Banana
}

\author{
Anna Nowembabazi ${ }^{*}$ (1), Godfrey Taulya ${ }^{2}$, William Tinzaara ${ }^{1}$ \\ ${ }^{1}$ Bioversity International, Kampala, Uganda \\ ${ }^{2}$ Department of Crop Production, Makarere University, Kampala, Uganda \\ Email: ^abernna@gmail.com
}

How to cite this paper: Nowembabazi, A., Taulya, G. and Tinzaara, W. (2021) Contribution of Biofertiliser (Frateuria auranta) in an Integrated Potassium Management Package on Growth of Apple Banana. Open Journal of Soil Science, 11, 521-537. https://doi.org/10.4236/ojss.2021.1111026

Received: August 31, 2021

Accepted: November 9, 2021

Published: November 12, 2021

Copyright $\odot 2021$ by author(s) and Scientific Research Publishing Inc. This work is licensed under the Creative Commons Attribution International License (CC BY 4.0).

http://creativecommons.org/licenses/by/4.0/

\begin{abstract}
Bananas demand high amounts of potassium for optimal growth and productivity, yet deficiencies are widespread amid the low input production strategy of smallholder farmers in Uganda. Of the potassium pool in the soil, 90\% $98 \%$ is unavailable for plant uptake. Judicious application of fertilisers is required to alleviate soil fertility problems complemented with manures and biofertilisers in an integrated nutrient management (INM) package. Biofertilisers such as potassium solubilising bacteria (KSB) have potential to solubilise unavailable forms of $\mathrm{K}$ in soil to forms that are readily absorbed by the plants. However, the added value of each component in this integrated $\mathrm{K}$ management package in apple bananas is not known. Therefore, an experiment was set up to quantify the relative contribution of mineral $\mathrm{K}$, manure and KSB on the growth of apple bananas. Potted tissue culture plantlets of apple banana (cv. Sukali ndiizi) were used. The treatments comprised of a full factorial combination of mineral fertiliser (Muriate of potash, $60 \% \mathrm{~K}_{2} \mathrm{O}$ ), animal manure and KSB (Frateuria auranta). The manure and muriate of potash were applied to supply a total of $150 \mathrm{~kg} \cdot \mathrm{K} \cdot \mathrm{ha}^{-}$. Soil microbiological assays were run to evaluate the contribution of indigenous microbial $\mathrm{K}$ solubilising activity in the soil to the experimental INM package. Data on pseudostem height, girth at collar and 30-cm height, leaf length and width at the widest point were collected once a week for 24 weeks. Bacillus, Pseudomonas and Frateuria were present as indigenous KSBs in the soil. The biofertiliser applied as $F$. auranta solubilised $7.4 \mathrm{mg} \cdot \mathrm{K} \cdot \mathrm{l}^{-1}\left(6.2 \mathrm{mg} \cdot \mathrm{K} \cdot \mathrm{kg}^{-1}\right)$ from soil minerals. The integrated $\mathrm{K}$ management package significantly $(\mathrm{p}<0.001)$ increased the above ground biomass and leaf area of potted apple bananas by up to $57.5 \%$ compared to no input. The Study recommends an economic analysis study to determine the integrated $\mathrm{K}$ management package that would suit the resource
\end{abstract}


constrained smallholder farmers.

\section{Keywords}

Apple Banana, Biomass Accumulation, Frateuria auranta, Leaf Area and Potassium Solubilising Bacteria

\section{Introduction}

Bananas demand a high amount of potassium yet smallholder farmers barely apply mineral fertilisers due to poor access and high prices [1]. Judicious use of mineral fertiliser is needed to overcome deficiencies [2] although it is reported to be costly financially and environmentally [3]. Application of manure can be helpful in alleviating $\mathrm{K}$ deficiencies [4] and minimising leaching losses but it is constrained by lack of access to adequate amounts for effective nutrient application rates. Using biofertilisers can reduce the need for external nutrient inputs [5] [6] which enable plants to exploit nutrient stocks from the soil more effectively. Out of the pools of $\mathrm{K}$ found in the soil, that in soil minerals make up $90 \%$ to $98 \%$ of the total content but it is unavailable for plant uptake [7].

Application of manure and biofertilisers in combination with inorganic fertilisers plays multiple important roles in growth and development of the plants as well as sustenance of soil fertility and environmental quality. This is the concept of Integrated Nutrient Management (INM). It has been shown to be effective in several horticultural crops [8]. It significantly increases the growth and yield of guavas [9], black gram [10] and banana cultivar Grande naine [8]. Integrated nutrient management lays emphasis on continuous improvement in soil productivity on long term basis through judicious use of mineral fertilisers, biofertilisers and manures and their proper management for optimum growth, yield and quality of crops in specific agro-ecological situation [11]. Manure is a broad term, which includes livestock excreta, left-over feed and other wastes from processing livestock products, household waste compost, crop residue composts and fresh plant materials applied to the soil for soil fertility management as green manures. Manure improves the soil physical, chemical and microbiological properties and ultimately the crop yield [5] [8].

Biofertilisers are preparations containing living or latent cells of efficient strains of microorganisms that facilitate crops' access to and/or uptake or assimilation of nutrients via their interactions with the crops in the rhizosphere [12] when applied on seed or directly to the soil. A wide range of bacteria namely: Bacillus mucilaginosus, Bacillus edaphicus, Bacillus circulans, Paenibacillus spp., Acidithiobacillus ferrooxidans, Pseudomonas sp., Burkholderia sp.

[13] and Frateuria aurantia [14] have been reported to release potassium in available form from potassium-bearing minerals in soils. These KSB were found to dissolve potassium [15], silicon and aluminium from insoluble K-bearing minerals such as micas, illite and orthoclases, by secreting organic acids which either 
directly dissolved the $\mathrm{K}$ in the mineral or chelated silicon ions to bring $\mathrm{K}$ into the solution [16]. Inoculation with KSB has been reported to improve growth of cotton and rape, pepper and cucumber, sorghum, wheat and Sudan grass [17].

Several INM studies have shown it to be effective in improving soil health, plant growth and productivity [8] [18] but in different plant species and geographical locations. None have investigated apple banana crop response to INM packages involving KSB, yet microbial activity tends to vary with environmental conditions. This study therefore was conceptualised to quantify the relative contribution of different $\mathrm{K}$ sources in an integrated nutrient management package (viz. K-solubilising bacteria, mineral $\mathrm{K}$ and organic manure) on the growth of apple bananas.

\section{Objectives}

The broad objective of this study was to develop an INM package for improving apple banana growth, sustaining soil fertility and maintaining environmental health via enhancement of the biological mechanisms for potassium dynamics from various pools in the soil.

\section{Specific objectives}

1) To assess the interactive effects of manure and inorganic $K$ fertiliser on the diversity of indigenous $\mathrm{K}$-solubilising microorganisms in the soil.

2) To assess the interactive effects of manure and inorganic $K$ fertiliser on the activity and abundance of $\mathrm{K}$-solubilising microorganisms in the soil.

3) To assess the relative contribution of manure, inorganic fertiliser $K$, manure and exotic KSB on the growth of apple bananas.

\section{Materials and Methods}

\subsection{Study Area}

The study was carried out at Kawanda National Agricultural Research Laboratories (NARL) located on $00^{\circ} 25^{\prime} \mathrm{N}$ and $32^{\circ} 31^{\prime} \mathrm{E}$ at an elevation of $1156 \mathrm{~m}$ above sea level. The area has two rainy seasons (March to May and September to December), with annual rainfall of $1250 \mathrm{~mm}$. Daily mean minimum and maximum temperatures are $15.3^{\circ} \mathrm{C}$ and $27.3^{\circ} \mathrm{C}$ respectively, while the relative humidity is on average $76.3 \%$ [19].

\subsection{Experimental Set Up and Data Collection}

The experiment was set up in a screen house. Pots of 10-liter capacity were perforated at the bottom for drainage and a 5-cm thick layer of sandy non-experimental soil added to facilitate rapid drainage. The pots were filled with soil sterilised using steam at $90^{\circ} \mathrm{C}$ for 2 hours. A randomised complete design was used with full factorial combination of the treatment factors KSB, mineral $\mathrm{K}$ fertiliser and manure (Table 1), replicated three times.

Potassium was applied as muriate of potash at the rate of $150 \mathrm{~kg} \cdot \mathrm{K} \cdot \mathrm{ha}^{-1}$. Dry manure was applied at a rate that is equivalent to $150 \mathrm{~kg} \cdot \mathrm{K} \cdot \mathrm{ha}^{-1}$. The combination of 
Table 1. Treatment structure.

\begin{tabular}{ccccccccc}
\hline Treatment & 1 & 2 & 3 & 4 & 5 & 6 & 7 & 8 \\
Biofertiliser (K solubilising bacteria) & 0 & 0 & 0 & 0 & 1 & 1 & 1 & 1 \\
Mineral K (Muriate of potash) & 0 & 1 & 0 & 1 & 0 & 1 & 0 & 1 \\
Manure & 0 & 0 & 1 & 1 & 0 & 0 & 1 & 1 \\
\hline
\end{tabular}

$1=$ applied; 0 = not applied

manure and muriate of potash was also aimed at supplying a total of $150 \mathrm{~kg} \cdot \mathrm{K} \cdot \mathrm{ha} \mathrm{a}^{-1}$ with half of it coming from the mineral fertiliser and the other half from the manure. The inputs were applied at planting. Liquid biofertiliser containing Frateuria auranta as a KSB was sprayed in the soil at a rate of $1 \mathrm{ltr} / \mathrm{ha}$ one week after application of muriate of potash.

The inputs were mixed with the soil (according to the treatment) before adding the soil to the pots. There were 8 pots per treatment, 3 replicates and 8 treatments in the trial giving a total of 192 pots. Each pot was planted with hardened tissue culture apple banana (cv. Sukali ndiizi) plantlet and watered adequately.

\subsection{Soil and Foliar Analysis}

Before application of inputs (i.e. manure, MOP or KSB) a soil and a manure sample was reserved for soil nutrients analysis. The samples were analysed for available N, P, K, Ca and soil organic carbon. Organic carbon was quantified calorimetrically at $600 \mathrm{~nm}$ after extraction with potassium dichromate and sulphuric acid [20]. Total nitrogen was extracted using sulphuric/selenium acid mixture at $330^{\circ} \mathrm{C}$ and then quantified calorimetrically using Nessler and Phenate method. The exchangeable cations ( $\mathrm{K}$ and $\mathrm{Ca}$ ) and available $\mathrm{P}$ were extracted using Mehlich 3 solution and quantified using an emission flame photometer and atomic absorption spectrometer, respectively. Twenty weeks after planting, the third fully expanded leaf with its leaf stalk was collected per treatment per replicate for foliar analysis. The leaf sample was placed in paper bags and oven dried to constant weight. The samples were finely ground and analysed for $\mathrm{N}, \mathrm{P}$ and $\mathrm{K}$ concentrations, the procedures of foliar analysis [21]. Soil $\mathrm{pH}$ was analysed using a $\mathrm{pH}$ meter at a ratio of 1:2.5, sample to water, and soil particle distribution done to determine the soil textural class [21].

\subsection{Microbial Analysis}

This was done to determine the abundance and activity of indigenous KSB in the soil. A soil sample per treatment per replicate was collected in sterilised collection bottles. The soil was then kept on ice to maintain microbial diversity until analysis. The samples were cultured using modified Aleksandrov medium containing $0.25 \%$ bromothymol blue indicator (BTB) incubated at $35^{\circ} \mathrm{C}-37^{\circ} \mathrm{C}$ for 24 - 48 hrs until cream to light yellow gel forms on the petri dishes [22]. 
The soil samples were serial diluted to $10^{-5}$ and each dilution was incubated for 24 hours on selective Aleksandrov medium with BTB. All colonies that grew on media and formed a halo solubilisation zone were considered to be potassium solubilising organisms. The colonies were counted using a colony counter and different colonies distinguished based on their morphological characteristics as used by [23]. The colony diameters were estimated using a ruler. Different colonies were isolated their gram staining reaction determined along with their respective cell shapes under microscopic observation. The different colonies were also subjected to a catalase test using hydrogen peroxide; the occurrence of gas bubbles was scored positive for catalase activity by the organisms.

Quantitative determination of solubilised potassium was done using the protocol by [7]. To quantify how much potassium was solubilised by Frateuria auranta (an organism inoculated in the soil for K-source), pure culture containing only $F$. auranta were inoculated in Aleksandrov broth media and grown for 10 days with constant shaking. The sample was analysed for $\mathrm{K}$ according to the procedure by [7] using an emission flame photometer. The sample was compared with Aleksandrov broth media where no organism was grown as the control.

\subsection{Data Analysis}

Soil and foliar samples data were analysed using a one-way analysis of variance (ANOVA) and the means separated using least significance difference (LSD) at 95\% confidence interval. Data on growth parameters were analysed using ANOVA using general treatment structure to separate the different factor effects and their means were also separated with LSD at $5 \%$. To compare the accumulated biomass, data were first loge transformed to fit the equations used to calculate biomass; the data were then analysed using a one-way ANOVA and means separated with LSD at 5\%. ANOVA was carried out to test the significance of the treatment differences in all analyses. All analyses were done using GenStat 12 edition software.

\section{Results}

\subsection{Analysis Results from Soil and Foliar Samples}

Manure contained N, P, K levels that were greater than the soil critical values. The Organic carbon content of $8.43 \%$ was also above the critical levels of $2.5 \%$ in soil. The soil sample used, however, was slightly higher than the soil critical values (Table 2).

The nutrient inputs doubled the $\mathrm{K}$ concentration in the leaves relative to the control but MOP had to be combined with either KSB or manure or both for maximum $\mathrm{K}$ concentration in the leaves (Table 3). Manure was necessary for increasing foliar $\mathrm{N}$ concentration relative to the control. On their own, KSB and MOP had no significant effect on foliar $\mathrm{N}$ concentration (Table 3). The trend in treatment effects on foliar $\mathrm{N}$ concentration was paralleled with that for foliar $\mathrm{P}$ (Table 3). The trend in treatment effects on foliar $\mathrm{K}$ concentration was paralleled 
Table 2. Soil and manure characteristics at planting.

\begin{tabular}{cccccccc}
\hline $\begin{array}{c}\text { Soil } \\
\text { characteristics }\end{array}$ & $\begin{array}{c}\text { pH water } \\
(1: 2.5)\end{array}$ & $\begin{array}{c}\text { Organic } \\
\text { Carbon (\%) }\end{array}$ & $\begin{array}{c}\text { Phosphorous } \\
(\mathrm{ppm})\end{array}$ & Nitrogen & $\begin{array}{c}\text { Potassium } \\
(\mathrm{cmol} / \mathrm{kg})\end{array}$ & Calcium & $\begin{array}{c}\text { Textural } \\
\text { class }\end{array}$ \\
\hline Soil sample & 5.64 & 2.85 & 83.76 & 0.56 & 0.16 & 2.25 & $\begin{array}{c}\text { sandy clay } \\
\text { loam }\end{array}$ \\
Manure & 6.61 & 8.43 & 170.17 & 3.08 & 0.28 & & \\
Soil critical values & & $<2.5$ & $<80$ & $<0.2$ & $<0.15$ & \\
\hline
\end{tabular}

${ }^{\S}$ Soil critical values based on tropical soil requirements by [24].

Table 3. Mean nutrient concentrations from foliar analysis per treatment

\begin{tabular}{ccccc}
\hline \multirow{2}{*}{ Treatment } & \multicolumn{5}{c}{ Nutrient concentration (\%) } \\
\cline { 2 - 5 } No input & $\mathrm{K}$ & $\mathrm{N}$ & $\mathrm{P}$ & $\mathrm{Ca}$ \\
\hline Muriate of potash (MOP) only & 2.31 & 1.18 & 1.43 & 0.31 \\
Manure only & 5.22 & 1.62 & 1.78 & 0.51 \\
MOP + manure & 5.10 & 2.43 & 2.20 & 0.51 \\
Potassium solubilising bacteria (KSB) only & 4.97 & 1.21 & 1.50 & 0.48 \\
KSB + MOP & 5.82 & 1.94 & 2.34 & 0.57 \\
KSB + manure & 5.67 & 2.70 & 2.33 & 0.61 \\
MOP + manure + KSB & 6.44 & 2.94 & 2.51 & 0.68 \\
LSD at 5\% confidence level & 1.08 & 0.72 & 0.88 & 0.12 \\
Fpr & 0.02 & 0.03 & 0.02 & 0.04 \\
\hline
\end{tabular}

with that for foliar Ca concentration except that KSB had to be combined with either MOP or manure or both for maximum foliar Ca concentration (Table 3).

\subsection{Soil Microbial Analysis}

The number of CFUs reduced with increasing dilution. At a given dilution, the control (no input) had the lowest number of CFUs (Table 4). Manure gave the highest number of CFUs among the sole input treatments. However, combining manure with KSB and MOP gave significantly higher number of CFUs than sole manure across dilutions, except at $\times 10^{-4}$. At moderate dilutions $\left(\times 10^{-3}\right.$ and $\left.\times 10^{-4}\right)$, manure was followed by KSB in increasing number of CFUs for the sole fertility input treatments. There was no significant difference in number of CFUs between KSB and MOP at the highest dilution $\left(\times 10^{-5}\right)$ while at the lowest dilution $\left(\times 10^{-2}\right)$, KSB had only $60 \%$ of the number of CFUs counted with sole MOP (Table 4). Combining manure with KSB gave more CFUs than combining manure with MOP across dilutions except at $\times 10^{-4}$ where they gave similar number of CFUs.

All the different microbial colonies (cells) on the petri dishes were rod-shaped. Their colony diameter ranged from $1.5 \mathrm{~mm}$ (small) to $6 \mathrm{~mm}$ (large). All the colonies reacted positively to the catalase test, but the Gram test showed both posi- 
tive and negative ones (Plate 1). The different colonies exhibited different colony morphological characteristics. Basing on the colony characteristics, gram stain reaction and catalase tests the observed microorganisms most probably belonged to the genera Bacillus, Pseudomonas and Frateuria (Table 5). Reference

Table 4. Mean number of counted microbial colonies at different serial dilution factors

\begin{tabular}{ccccc}
\hline \multirow{2}{*}{ Treatment } & \multicolumn{3}{c}{ CFU } \\
\cline { 2 - 5 } & $\times 10^{-2}$ & $\times 10^{-3}$ & $\times 10^{-4}$ & $\times 10^{-5}$ \\
\hline T1 no input & 33.7 & 5.0 & 1.7 & 0.0 \\
T2 MOP & 51.7 & 9.3 & 4.0 & 1.3 \\
T3 Manure & 160.0 & 95.7 & 37.7 & 10.3 \\
T4 MOP $\times$ Manure & 117.3 & 65.3 & 24.7 & 5.0 \\
T5 KSB & 30.3 & 14.0 & 6.0 & 0.3 \\
T6 KSB $\times$ MOP & 62.0 & 19.7 & 5.3 & 1.7 \\
T7 KSB $\times$ Manure & 215.7 & 119.0 & 25.7 & 13.3 \\
T8 KSB $\times$ MOP $\times$ Manure & 222.0 & 120.3 & 29.3 & 12.7 \\
Lsd @5\% & 6.8 & 3.1 & 3.5 & 1.7 \\
Fpr & & & 0.001 &
\end{tabular}

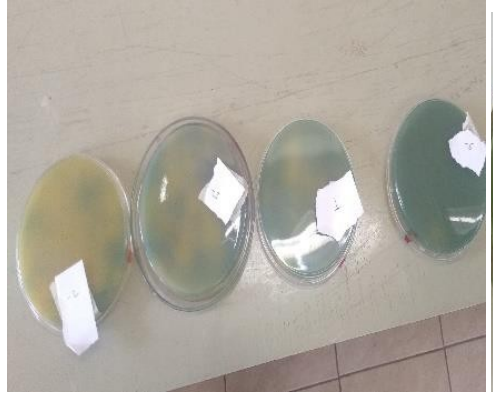

(a)

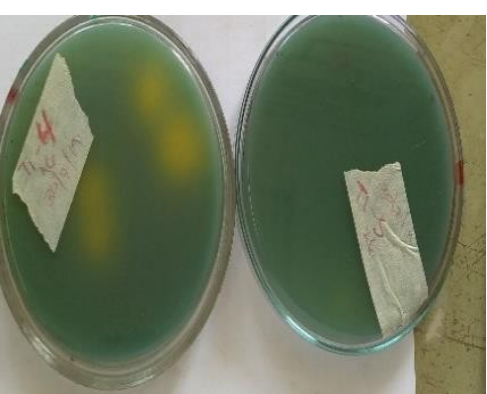

(b)

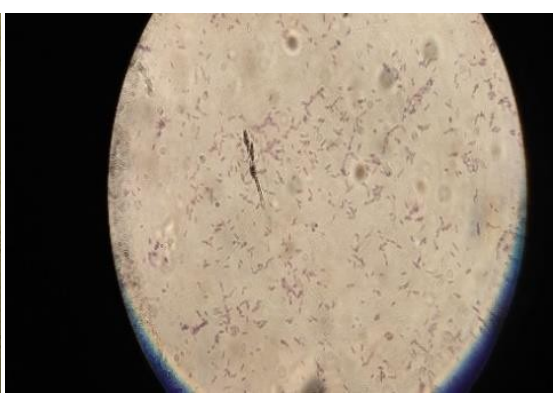

(c)

Plate 1. Colony forming units at different serial dilution factors (a) and (b) yellow halo-zone caused by KSB against control, (c) gram-ve rods of Frateuria auranta.

Table 5. Colony characteristics observed from different colonies formed on Aleksandrov media.

\begin{tabular}{ccccccc}
\hline Isolate & Colony morphological characteristics & $\begin{array}{c}\text { Gram staining } \\
\text { reaction }\end{array}$ & $\begin{array}{c}\text { Cell } \\
\text { shape }\end{array}$ & $\begin{array}{c}\text { Colony } \\
\text { diameter (mm) }\end{array}$ & $\begin{array}{c}\text { Catalase } \\
\text { test }\end{array}$ & $\begin{array}{c}\text { Probable } \\
\text { genus }\end{array}$ \\
\hline 1 & White, viscid, round, flat, opaque, small & + & Rods & 1.5 & + & Bacillus \\
2 & White, viscid, round, raised, opaque, large & + & Rods & 3 & Bacillus \\
3 & Yellow, dry, flat, round & - & Rods & 2 & + & Pseudomonas \\
4 & Yellow, opaque, flat, irregular & - & Rods & 2 & + & Pseudomonas \\
4 & Creamy, opaque, viscid, raised, irregular, large & - & Rods & 6 & Pseudomonas \\
5 & Brown, flat, opaque, small & - & Rods & 1.5 & - & Frateuria \\
\hline
\end{tabular}




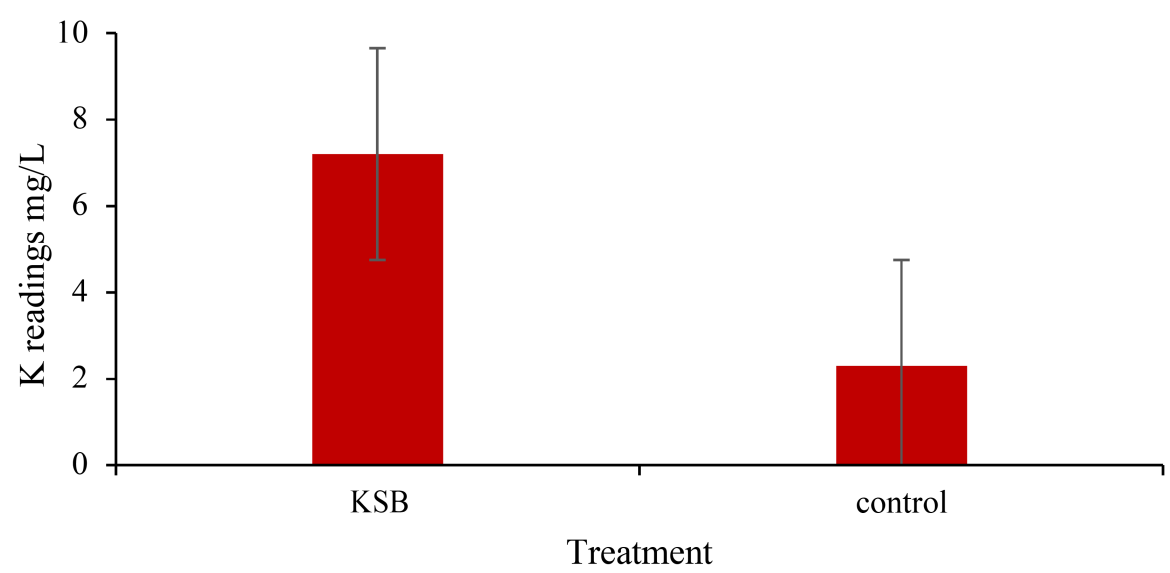

Figure 1. Quantification of K solubilised by Frateuria auranta.

KSB Frateuria solubilised $7.4 \mathrm{mg} \cdot \mathrm{K} \cdot \mathrm{l}^{-1}$ (equivalent to $6.2 \mathrm{mg} \cdot \mathrm{K} \cdot \mathrm{kg}^{-1}$ or approximately $25 \mathrm{~kg} \cdot \mathrm{K} \cdot \mathrm{ha}^{-1}$ in the $0-30 \mathrm{~cm}$ depth layer of a soil with a dry bulk density of $1330 \mathrm{~kg} \cdot \mathrm{m}^{-3}$ ) of readily available potassium from the insoluble potassium source of potassium aluminium silicate (Figure 1).

\subsection{Effects of integrated potassium management on growth}

Application of potassium significantly increased the growth parameters of apple bananas. Height was significantly increased by the $\mathrm{K}$ input, regardless of source, by between 14 and $23 \%$ relative to the control (Table 6). However, manure was required for maximum increase in plant height relative to the control both as a sole input ( $18 \%$ increase) and in combination with either MOP (18\% increase) or with KSB (22\% increase), or with both KSB and MOP (23\% increase). This trend was maintained regarding the plant girth with the increase relative to the control ranging from 19\% (sole MOP) to 33\% (combination of manure, KSB and MOP). Leaf width was the most strongly affected leaf growth parameter due to application of the inputs in this study. The increase in leaf width relative to the control ranged from $22 \%$ (sole KSB) to $47 \%$ (combination of manure, KSB and MOP). This trend was maintained with respect to leaf length and number of functional leaves though with lower percentage increases. However, sole KSB did not significantly affect the number of functional leaves while sole manure had no significant effect on the leaf width (Table 6). Just like for the plant height and girth parameters, the combination of manure, KSB and MOP was necessary to achieve maximum increase in the leaf growth parameters. Interactions of the different potassium input combinations were also statistically significant.

Input effects were not visible at the beginning of the experiment but over time, application of inputs recorded marked increase pseudostem height over the control (Figure 2). Application of manure recorded higher readings than either sole MOP or sole KSB. Manure and KSB highly masked the effect of MOP overtime. Similarly, MOP $\times$ Manure was also highly masked by the effects of MOP $\times$ KSB and KSB $\times$ Manure. There was no significant difference over time as a result of application of these input combinations (Figure 2). Comparison of 
Table 6. Effect of different potassium sources on apple banana growth parameters.

\begin{tabular}{|c|c|c|c|c|c|c|c|}
\hline \multicolumn{3}{|c|}{ Treatment factors } & \multicolumn{2}{|c|}{ Pseudo-stem } & & \multicolumn{2}{|c|}{ Functional Leaf } \\
\hline & & & Height & Girth & length & width & Number \\
\hline KSB & MOP & Manure & \multicolumn{5}{|c|}{$\mathrm{cm}$ means \pm sed } \\
\hline 0 & 0 & 0 & $42.16 \pm 0.72$ & $8.48 \pm 0.68$ & $31.77 \pm 1.15$ & $10.70 \pm 0.44$ & $4.32 \pm 0.14$ \\
\hline 0 & 1 & 0 & $48.04 \pm 1.65$ & $10.11 \pm 0.48$ & $37.40 \pm 1.36$ & $13.26 \pm 0.88$ & $4.78 \pm 0.20$ \\
\hline 0 & 0 & 1 & $49.77 \pm 1.21$ & $10.72 \pm 0.37$ & $38.47 \pm 1.10$ & $14.62 \pm 0.59$ & $5.17 \pm 0.10$ \\
\hline 0 & 1 & 1 & $49.79 \pm 0.65$ & $10.68 \pm 0.16$ & $38.69 \pm 0.49$ & $14.90 \pm 0.28$ & $5.20 \pm 0.06$ \\
\hline 1 & 0 & 0 & $48.86+1.28$ & $10.29 \pm 0.39$ & $37.50 \pm 1.15$ & $13.02 \pm 0.27$ & $4.49 \pm 0.18$ \\
\hline 1 & 1 & 0 & $49.11 \pm 0.65$ & $10.70 \pm 0.16$ & $38.16 \pm 0.49$ & $14.57 \pm 0.28$ & $4.71 \pm 0.04$ \\
\hline 1 & 0 & 1 & $51.34 \pm 0.64$ & $10.82 \pm 0.15$ & $38.57 \pm 0.95$ & $14.89 \pm 0.27$ & $5.02 \pm 0.04$ \\
\hline 1 & 1 & 1 & $51.69 \pm 0.91$ & $11.26 \pm 0.21$ & $40.45 \pm 0.69$ & $15.72 \pm 0.75$ & $5.13 \pm 0.09$ \\
\hline \multicolumn{3}{|c|}{$\underline{\text { Lsd @ } 5 \%}$} & 1.78 & 0.42 & 1.34 & 0.76 & 0.17 \\
\hline \multicolumn{8}{|c|}{ Source of variation } \\
\hline \multicolumn{8}{|l|}{ KSB } \\
\hline \multicolumn{3}{|l|}{ MOP } & \multicolumn{5}{|c|}{$<0.001$} \\
\hline \multicolumn{8}{|c|}{ Manure } \\
\hline \multicolumn{3}{|c|}{$\mathrm{KSB} \times \mathrm{MOP}$} & $<0.001$ & $<0.05$ & $<0.05$ & ns & Ns \\
\hline \multicolumn{3}{|c|}{$\mathrm{KSB} \times$ Manure } & $<0.05$ & $<0.001$ & $<0.05$ & $<0.001$ & $<0.05$ \\
\hline \multicolumn{3}{|c|}{ Manure $\times$ MOP } & $<0.001$ & $<0.001$ & $<0.001$ & $<0.001$ & $<0.05$ \\
\hline \multicolumn{3}{|c|}{$\mathrm{KSB} \times \mathrm{MOP} \times$ Manure } & $<0.05$ & $<0.001$ & $<0.001$ & $<0.05$ & $<0.05$ \\
\hline
\end{tabular}

1-applied, 0-not applied, KSB-Potassium solubilising bacteria, MOP-muriate of potash (inorganic K), sed; standard error of means.

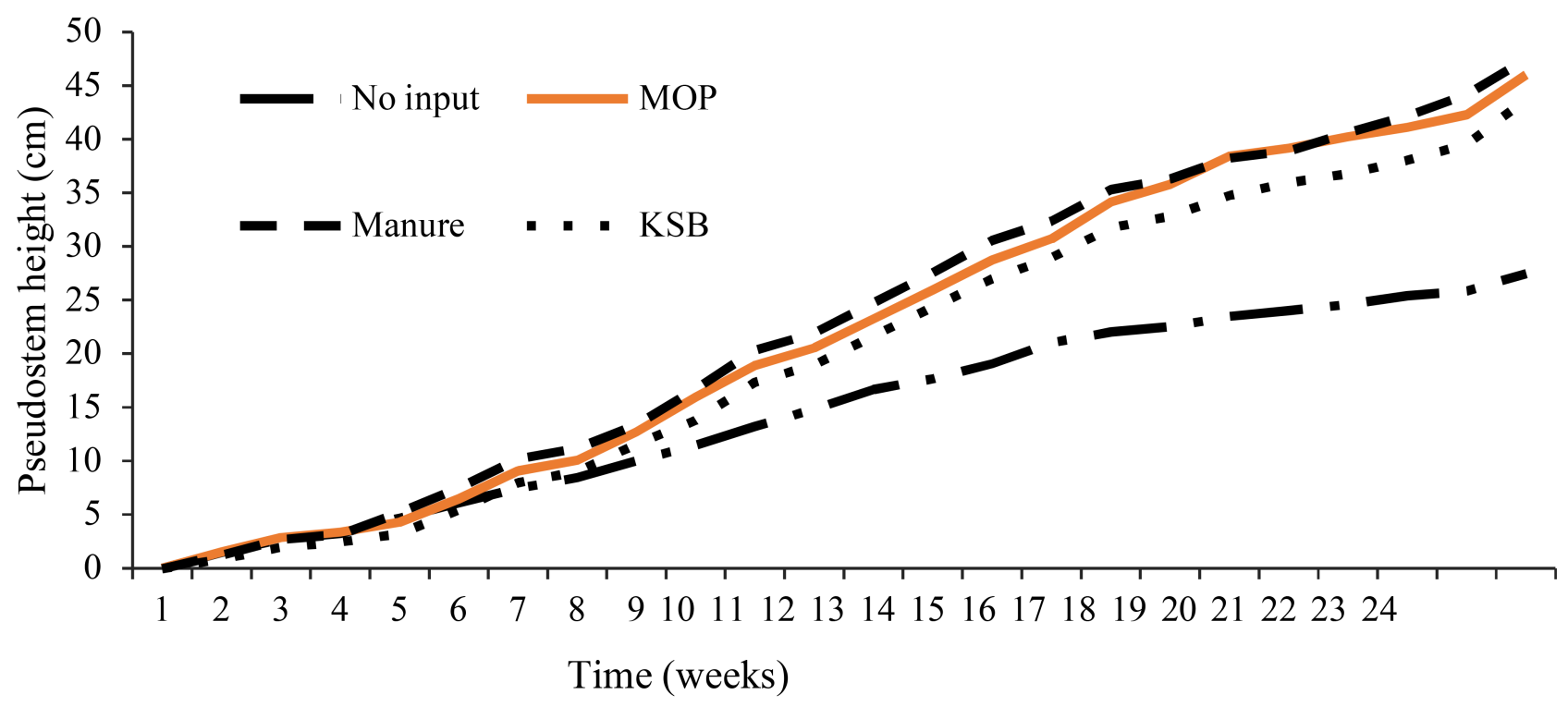

Figure 2. Sole input vs. control and different input interactions. 
all input combinations against no input indicated a marked and significant increase in pseudostem height overtime However, a comparison of all treatments, showed no a distinct difference among treatments except for T1 (no input Figure 3).

The above ground biomass and total biomass as estimated by girth at $30 \mathrm{~cm}$ and girth at collar were not significantly different ( $\mathrm{t}$ probability $=-0.08$ for d.f $=$ 7; F.Pr $=0.434$ and t probability $=-1.29$ at d.f $=7$; F. Pr 0.238 for AGB and TB respectively). Application of potassium irrespective of the input source increased accumulated biomass content of apple bananas. Treatment T1 where no input was applied significantly recorded low AGB as well as TB. Treatments T4 (manure and MOP) and T8 (all inputs) recorded significant differences ( $\mathrm{p}<0.001)$ in AGB and TB in comparison to all other treatments (Table 7).

As was observed in accumulated biomass, treatment $\mathrm{T} 1$ recorded significantly low ( $\mathrm{p}<0.001$ ) leaf area than all the other treatments. Treatments T2 (MOP alone) and T5 (KSB alone) also were observed to record significantly low leaf area as compared to the rest of the treatments. Treatments which received manure as an input were observed to obtain higher leaf area although the difference were not statistically significant (Table 7).

\section{Discussion}

Results of soil analysis indicated that the exchangeable potassium $(0.16 \mathrm{cmol} / \mathrm{kg})$ in the soil was moderate comparing critical values of tropical soils, where less than $0.15 \mathrm{cmol} / \mathrm{kg}$ is below optimum [25]. However, this value was far below the critical required level of $1.3 \mathrm{cmol} / \mathrm{kg}$ required by bananas suggested by [26]. Nitrogen and organic matter were above the critical levels of $0.2 \%$ and $2.5 \%$ respectively

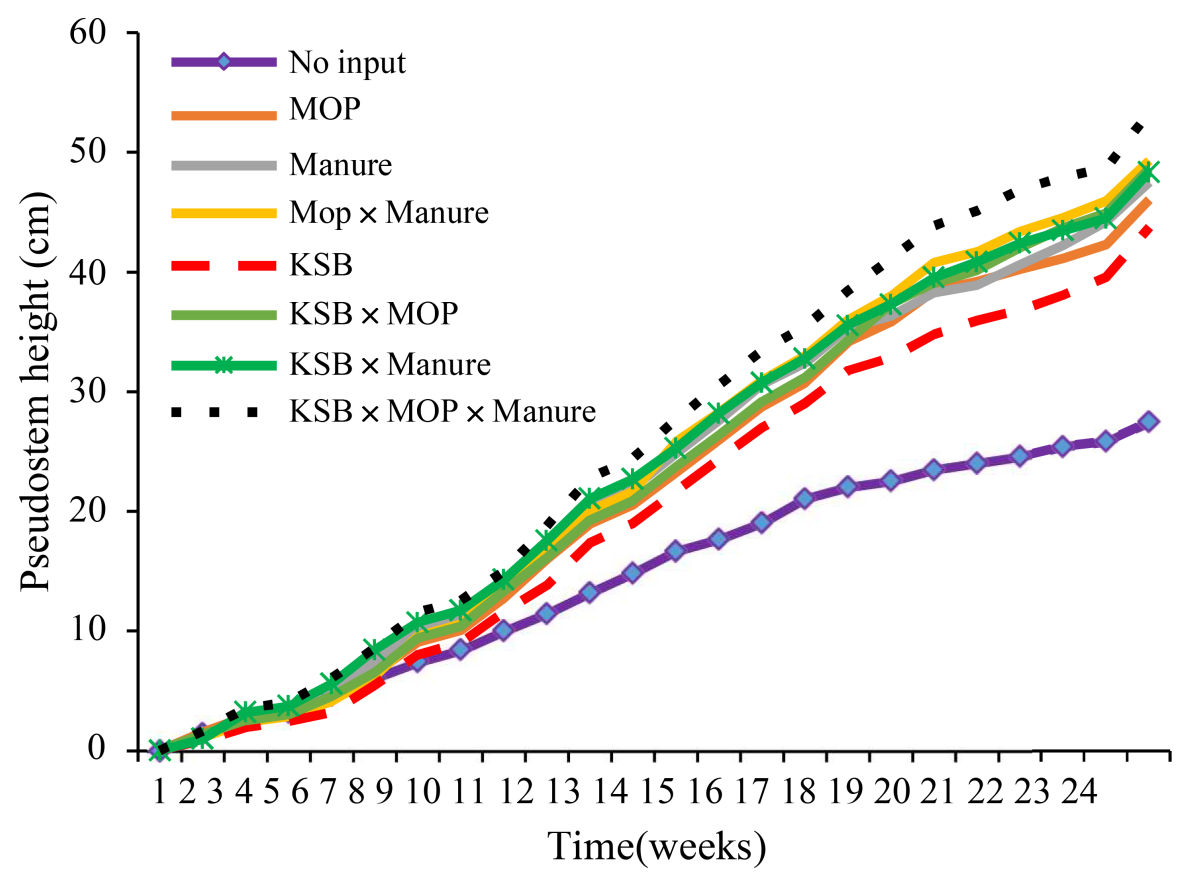

Figure 3. Control vs. all inputs and comparison of all treatments together. 
as quoted by [27].

Foliar analysis results, however, indicated that treatment with no input had significantly low $\mathrm{K}(2.3 \%)$ than all the other treatments and it was also below the critical level of 3.0\% of bananas [28]. Treatments of manure and inorganic $\mathrm{K}$ (T4) and treatment with all inputs (T8) recorded the highest $\mathrm{K}$ content $>6.0 \%$ and these were significantly higher than values obtained in treatment of MOP alone (5.22\%) and KSB alone (4.97\%). Nitrogen was below the critical levels of $2.6 \%$ according to [28] in all treatments except those treatments where manure was applied. It was highest in T8 (all inputs) of $2.9 \%$ followed by manure and MOP (T4) of 2.8 and then MOP and KSB (T7) of 2.7\% (Table 3). This was an indicator that the manure supplied the $\mathrm{N}$ that supplemented that from the soil for the plant requirement for growth.

Application of manure also had a significant contribution to the soil microbial content (Table 4). This could be because most microbes are organotrophic and therefore their activity increased as a response to application of manure [29] [7]. Application of manure to the soil boosted the microbial growth hence the high numbers in manure treatments. Treatments T1 (no input) and T2 (MOP only) also had living organisms (Table 4) despite sterilisation. These organisms could have been introduced into the pots from the potting mixture, but did not increase.

The probable organisms found in the study were from Bacillus, Pseudomonas and Frateuria genera (Table 5). Frateuria was KSB from the inoculant. Pseudomonas and Bacillus spp could have been introduced with manure, because they play an important part in the process of decomposition [17] [30]. Among the soil bacterial communities, B. mucilaginosus, B. edaphicus and B. circulanscan

Table 7. Above ground and total biomass as estimated using girth at $30 \mathrm{~cm}$ and leaf area as estimated using allometric equations.

\begin{tabular}{ccccc}
\hline Treatments & G-30 (cm) & AGB $(\mathrm{g})$ & TB $(\mathrm{g})$ & Leaf area $\left(\mathrm{cm}^{2}\right)$ \\
\hline T1-No input & 6.0 & 18.9 & 40.4 & 396 \\
T2-MOP alone & 7.8 & 30.1 & 65.4 & 550 \\
T3-Manure alone & 7.7 & 28.1 & 60.9 & 900 \\
T4-Manure + MOP & 9.9 & 44.7 & 98.4 & 805 \\
T5-KSB alone & 6.6 & 21.8 & 46.8 & 624 \\
T6-KSB + MOP & 8.3 & 32.7 & 71.1 & 829 \\
T7-KSB + Manure & 7.9 & 29.9 & 65.0 & 910 \\
T8-KSB + Manure + MOP & 9.8 & 44.5 & 97.9 & 929 \\
Lsd@5\% & 0.8 & 1.2 & 1.2 & 170 \\
F Pr-value & & $<0.001$ & &
\end{tabular}

ABG: above ground biomass, TB: total biomass, G-30: girth at $30 \mathrm{~cm}$; equations used: $\mathrm{y}=$ $1.70 \mathrm{G} 30-0.07$ for $\mathrm{ABG}$ and $\mathrm{y}=1.76 \mathrm{G} 30+0.59$ for total biomass [24]; AGB; $\mathrm{t}=-0.08$, d.f $=7$ probability $=0.434 \mathrm{~TB} ; \mathrm{t}=-1.29$, d.f $=7$, probability $=0.238$ at $5 \%$ LSD. 
have been described as effective K solubilisers [13], although this study did not identify the microorganisms to species level.

Frateuria auranta used in this study was able to released potassium from potassium aluminium silicate mineral in Aleksandrov broth of $7.4 \mathrm{mg} / \mathrm{l}$ in a period of 10 days of inoculation (Figure 1). This was higher than $4.2 \mathrm{mg} / \mathrm{l}$ reported by [31] using B. mucilaginosus in media supplemented with muscovite mica. The observed $\mathrm{K}$ solubilisation rate in this study was only $5 \%$ of that from bacterial strains isolated by [7], solubilised up to $400 \mathrm{mg} / \mathrm{l} \mathrm{K}$ from potassium aluminium silicate in 28 days, although their strains were not taxonomically identified.

Potassium solubilising bacteria are able to solubilise insoluble $\mathrm{K}$ from forms such as micas, illites, quartz, orthoclases [32] through production of organic acids. Acid production was observed in this study by organisms turning BTB modified media from blue ( $\mathrm{pH} 7.2 \pm 0.2$ ) to yellow, indicating $\mathrm{pH}$ change to acidic; although this study did not isolate the different acids produced. Microorganisms including KSB can have a considerable role in providing $\mathrm{K}$ to plant by storing $\mathrm{K}$ in their biomass (a significant quantity of fixed $\mathrm{K}$ ), which is potentially available to plants [33]. All these mechanisms of $\mathrm{K}$ solubilisation could have contributed to the amount of $\mathrm{K}$ observed to have been released by $F$. auranta used in this study.

Potassium application whether from MOP, KSB or manure significantly increased growth (height, girth, leaf length and width) as compared to no input at all (Table 6; Figure 2 and Figure 3). This was in agreement to other fertiliser trials conducted on banana in many studies in the world [1] [27] [34] [35]. Single input application (MOP alone, Manure or KSB alone) also significantly ( $\mathrm{p}<$ 0.001) increased the growth of apple bananas as compared to the control where no input was applied (Table 6) although MOP alone effect was highly masked by application of manure and KSB. This was an indication that sufficient application of manure or KSB caused as much effect on growth of apple bananas as where MOP was used. Use of alternative sources to MOP would be a beneficial factor to alleviating the cost effects of high prices which farmers cannot afford [2].

Integrating different $\mathrm{K}$ sources together $(\mathrm{MOP} \times$ Manure, $\mathrm{MOP} \times \mathrm{KSB}, \mathrm{KSB} \times$ Manure) generated a much greater effect on the growth of bananas (Table 6). These findings are in line with those of [8], where a combination bio fertilisers and manure produced significant effects on the growth of banana cultivar Grande naine than use of inorganic fertilisers lone. KSB $x$ Manure was statistically significant at $\mathrm{p}<0.05$ on growth parameters of stem girth, leaf width and number of functional leaves. Using all the inputs together (KSB x Manure x MOP) also significantly affected pseudo-stem height, leaf length, leaf width and number of functional leaves at $p<0.05$. On all other parameters, the different factor combinations were significant at $\mathrm{p}<0.001$. Similar trends were observed on different factor combinations on the growth parameters over time (Figure 2 and Figure $3)$. 
The results of the study showed that using KSB alone, did not have significant effects over the treatments where KSB was applied with Manure or MOP (Table 6; Figure 2 and Figure 3). This is in line with [7] [23], that KSB requires a carbon source for their own growth and biomass accumulation. Therefore, application of KSB in soils with low organic matter would not produce significant effects on growth. Therefore, application of KSB $\mathrm{x}$ Manure produced a greater impact on the growth parameters than where MOP was applied with manure (Table 6). Application of manure has additional benefits to the soil such as supplying nitrogen, organic matter, buffering rapid changes in soil $\mathrm{pH}$ and increasing the diversity and activity of beneficial soil microorganisms responsible for growth in plants [4].

Common farmer practice is use of manure alone, although this study indicated that with manure alone plants are able to outperform sole mineral $\mathrm{K}$ (Table 6), application of manure in their fields is usually below the required levels of 13 t/ha/yr [27] [36]. Therefore, augmenting application of manure with MOP or KSB shows potential for enhanced growth, and possibly higher yields due to additional nitrogen. [37] observed higher pseudo-stem height and girth in treatments with higher $\mathrm{N}$ and $\mathrm{K}$ input.

Integrated application of MOP $\times \mathrm{KSB} \times$ Manure (T8) resulted into higher significant accumulated biomass than no input or sole mineral $\mathrm{K}$ input application (Table 7). This is in agreement with the results obtained by [38] in Cotton where they used farm yard manure, biofertiliser and inorganic fertiliser to achieve high levels of dry matter accumulation. [39] observed that biomass accumulation in Sukali ndiizi (apple banana) was more influenced by available moisture content in the soil, explaining the $22.9 \mathrm{~g}$ and $40.4 \mathrm{~g}$ of AGB and TB respectively obtained in a treatment in their moisture stress study where there was no fertiliser input. However, treatment T8 (combination of KSB, manure and MOP) in this study recorded, $36.1 \mathrm{~g}$ and $97.9 \mathrm{~g}$ for $\mathrm{AGB}$ and $\mathrm{TB}$, respectively that translates into $57.5 \%$ and $142 \%$ increase over the control which this study attributes to effect of proper nutrition. This also agrees with [39] that proper nutrition of plants is manifested by the biomass accumulated by the plant.

Highest above ground and total biomass was obtained in treatments combinations with manure (T4-Manure $\times$ MOP, T7-KSB $\times$ Manure and T8-MOP $\times$ Manure $\times \mathrm{KSB}$ ). This could have been because manure provided nitrogen apart from $\mathrm{K}$, thus promoting vegetative growth more vigorously than other treatments [40]. The same trends were observed with regard to leaf area; highest was recorded in T8 and this was statistically significant to no input and single input application. Application of fertiliser (potassium) increased leaf area and biomass accumulation in apple bananas which allies with the findings of [41].

\section{Conclusions}

Application of manure, MOP or KSB increased the diversity of organisms capable of K-solubilisation in the soil. Manure application had the highest diversity 
of microorganisms, with probable species belonging to the genera of Bacillus and Psuedomonas. F. auranta used as KSB inoculum in the study recorded $7.2 \mathrm{mg} / \mathrm{l}$ of K-solubilised from potassium aluminium silicate in the Aleksandrov medium.

Application of MOP, Manure or KSB significantly increased the growth of apple bananas. Input combinations such as $\mathrm{KSB} \times \mathrm{MOP}, \mathrm{KSB} \times$ Manure or KSB $\times$ Manure $\times$ MOP gave more significant results than single input use. It was further observed that for optimisation of KSB, better results are achieved with use of manure. Use of KSB as a source of potassium produced same or better results with use of MOP. Considering the high market prices of MOP, using KSB as an alternative $\mathrm{K}$ source to the soil would be more attractive to small scale resource poor apple banana farmers.

It was found that total and above ground biomass in apple bananas increased in treatment combinations with manure (i.e. Manure $\times$ MOP, Manure $\times$ KSB or Manure $\times \mathrm{KSB} \times \mathrm{MOP})$. Therefore, this study recommends a further economic analysis to determine the most effective source of banana nutrition treatment that can be adopted by the resource constrained smallholder farmers. The study also recommends that these treatments which were studied in confined environments and on young plants, should be repeated in open field environments and grown plants of apple bananas.

\section{Conflicts of Interest}

The authors declare no conflicts of interest regarding the publication of this paper.

\section{References}

[1] Ochola, D., Ocimati, W., Tinzaara, W., Blomme, G. and Karamura, E. (2014) Interactive Effects of Fertiliser and Inoculum Concentration on Subsequent Development of Xanthomonas Wilt in Banana. African Journal of Agricultural Research, 9, 2727-2735. https://doi.org/10.5897/AJAR2014.8787

[2] Nyombi, K., van Asten, P.J.A., Corbeels, M., Taulya, G., Leffelaar, P.A. and Giller, K.E. (2010) Mineral Fertiliser Response and Nutrient Use Efficiencies of East African Highland Banana (Musa spp., AAA-EAHB, cv. Kisansa). Field Crops Research, 117, 38-50. https://doi.org/10.1016/j.fcr.2010.01.011

[3] Mohammadi, K. and Sohrabi, Y. (2012) Bacterial Biofertilisers for Sustainable Crop Production: A Review. ARPN Journal of Agricultural and Biological Science, 7, 307-316.

[4] Bekunda, M. (1999) Farmers' Responses to Soil Fertility Decline in Banana-Based Cropping Systems of Uganda. Managing Africa's Soils, No. 4.

[5] Hazarika, T.K. (2011) Evaluation of Integrated Nutrient Management Packages for Growth, Yield and Quality of Banana cv. Grand Naine in Mizoram. Thesis, Fulfilment of the Degree of Doctor of Philosophy (PhD) in Horticulture, Aromatic and Medicinal Plants. Mizoram University Aizawl, Mizoram.

[6] Velazquez, E., Silva, L.R., Ramirez-Balena, M. and Peix, A. (2016) Diversity of Potassium Solubilising Microorganisms and Their Interactions with Plants. In: Meena, V.S., Maurya, B.R., Verma, J.P. and Meena, R.S., Eds., Potassium Solubilizing Microorganisms for Sustainable Agriculture, Springer, Berlin, 99-110. https://doi.org/10.1007/978-81-322-2776-2_7 
[7] Parma, P. and Sindhu, S.S. (2013) Potassium Solubilisation by Rhizosphere Bacteria: Influence of Nutritional and Environmental Conditions. Journal of Microbiology Research, 3, 25-31.

[8] Hazarika, T.K., Bhattacharyya, R.K. and Nautiyal, B.P. (2014) Growth Parameters, Leaf Characteristics and Nutrient Status of Banana as Influenced by Organics, Biofertilisers and Bioagents. Journal of Plant Nutrition, 38, 1275-1288. https://doi.org/10.1080/01904167.2014.957399

[9] Bhalerao, V.P., Patil, N.M., Badgujar, C.D. and Patil, D.R. (2009) Studies on Integrated Nutrient Management for Tissue Cultured Grande Naine Banana. Indian Journal of Agricultural Research, 43, 107-112.

[10] Selvamani, P., Manivannan, K. and Mohan, J. (2011) Impact of Organic Manures, Inorganic Fertilisers and Biofertilisers on the Nutrient Concentration in Soil at Different Growth Stages of Banana cv. Poovan Mysore (AAB) (Musa sp. L).

[11] Chandra, K. and Greep, S. (2006) Potassium Mobilizing Bacteria (Frateuria aurentia). Regional Centre of Organic Farming, Bangalore, 72 p.

[12] Vessey, K.J. (2003) Plant Growth Promoting Rhizobacteria as Biofertilisers. Plant and Soil, 255, 571-586. https://doi.org/10.1023/A:1026037216893

[13] Meena, S.V., Maurya, B.R. and Verma, P.J. (2013) Does a Rhizospheric Microorganism Enhance $\mathrm{K}^{+}$Availability in Agricultural Soils. Microbiological Research, 169, 337-347. https://www.elsevier.com/locate/micres

[14] Marwaha, B.C. (1995) Biofertilisers-A Supplementary Source of Plant Nutrient. Fertiliser News, 40, 39-50.

[15] Prajapati, K.B. and Modi, H.A. (2012) Isolation and Characterization of Potassium Solubilising Bacteria from Ceramic Industry Soil. CIBTech Journal of Microbiology, 1, 8-14.

[16] Prajapati, K. and Modi, H.A. (2012). The Importance of Potassium in Plant Growth-A Review. Indian Journal of Plant Sciences, 2-3, 177-178.

[17] Basak, B.B. and Biswas, D.R. (2010) Co-Inoculation of Potassium Solubilising and Nitrogen Fixing Bacteria on Solubilisation of Waste Mica and Their Effect on Growth Promotion and Nutrient Acquisition by a Forage Crop. Biology and Fertility of Soils, 46, 641 -648. https://doi.org/10.1007/s00374-010-0456-x

[18] Kuttimani, R., Velayudham, K., Somasundaram, E. and Muthukrishnan, P. (2013) Effect of Integrated Nutrient Management on Yield and Economics of Banana.

[19] Nyombi, K. (2013) Towards Sustainable Highland Banana Production in Uganda: Opportunities and Challenges. African Journal of Food, Agriculture, Nutrition and Development, 13, 7544-7561.

[20] Walkley, A. and Black, I.A. (1934) An Estimation of the Digestion Method for Determination Soil Organic Matter and a Proposed Modification on the Cromic Acid Titration Method. Soil Science, 34, 29-38. https://doi.org/10.1097/00010694-193401000-00003

[21] Okalebo, J.R., Gathua, K.W. and Woomer, P.L. (2002) Laboratory Methods of Soil and Plant Analysis: A Working Manual. 2nd Edition.

[22] Aleksandrov, V.G., Blagodyr, R.N. and Illev, I.P. (1967) Liberation of Phosphoric Acid from Apatite by Silicate Bacteria. Mikrobiology Zh (Kiev), 29, 111-114.

[23] Archada, D.S. (2007) Studies on Potassium Solubilising Bacteria. M.sc. Thesis, University of Agricultural Sciences, Dharwad.

[24] Nowembabazi, A., Taulya, G. and Tinzaara, W. (2021) Allometric Functions for Apple Banana Leaf Area and above Ground Biomass. African Journal of Agricultural 
Research, 17, 1229-1236. https://doi.org/10.5897/AJAR2021.15478

[25] Koné, B., Traore, L., Sehi, Z.S., Kouassi, K. and O’neill, C. (2016) Characteristics of Soil Exchangeable Potassium According to Soil Colour and Landscape in Ferralsols Environment. Cogent Geoscience, 2, Article ID: 1199523. https://doi.org/10.1080/23312041.2016.1199523

[26] McIntyre, B.D., Speijer, P.R., Riha, S.J. and Kizito, F. (2000) Effects of Mulching on Biomass, Nutrients, and Soil Water in Banana Inoculated with Nematodes. Agronomy Journal, 92, 1081-1085. https://doi.org/10.2134/agronj2000.9261081x

[27] Odeke, M., Rubaihayo, P.R. and Osiru, D.S.O. (1999) Effect of Spacing, Stage and Method of Desuckering on Bunch Size and Yield of Banana Cultivar Kibuzi (AAA-EA). African Crop Science Journal, 7, 349-353. https://doi.org/10.4314/acsj.v7i4.27729

[28] Memon, N., Memon, S.K., Anwar, R., Ahmad, S. and Nafees, M. (2010) Status and Response to Improved NPK Fertilization Practices in Banana. Pakistan Journal of Bo$\operatorname{tany}, 42,2369-2381$.

[29] Etasami, H., Emami, S. and Alikhani, A.H. (2017) Potassium Solubilising Bacteria (KSB): Mechanisms, Promotion of Plant Growth, and Future Prospects-A Review. University of Tehran, Tehran. https://doi.org/10.4067/S0718-95162017000400005

[30] Sharma, A., Kher, R., Wali, V.K. and Bakshi, P. (2009) Effect of Biofertilisers and Organic Manures on Physico-Chemical Characteristics and Soil Nutrient Composition of Guava (Psidium guajava L.) cv. Sardar. SKUAST Journal of Research, 8, 150-156.

[31] Sugumaran, P. and Janarthanam, B. (2007) Solubilization of Potassium Containing Minerals by Bacteria and Their Effect on Plant Growth. World Journal of Agricultural Sciences, 3, 350-355.

[32] Shanware, A.S., Kalkar, S.A. and Trivedi, M.M. (2014) Potassium Solublisers: Occurrence, Mechanism and Their Role as Competent Biofertilisers. International Journal of Current Microbiology and Applied Sciences, 3, 622-629.

[33] Taulya, G. (2013) East African Highland Bananas (Musa spp. AAA-EA) "Worry" More about Potassium Deficiency than Drought Stress. Field Crops Research, 151, 45-55. https://doi.org/10.1016/j.fcr.2013.07.010

[34] Al-Harthi, K. and Al-Yahyai, R. (2009) Effect of NPK Fertiliser on Growth and Yield of Banana in Northern Oman. Journal of Horticulture and Forestry, 1, 160 -167.

[35] Kalhoro, S.A., Xu, X.X., Mahar, A., Ali, A., Kalhoro, F.A., Otho, S.A., Soomro, R.N., Ali, F. and Baloch, Z. (2015) Study on Growth Effects of Major-Nutrients Composition to Banana Cultivation in Coastal Areas of Sindh, Pakistan. American Journal of Plant Sciences, 6, 1003-1010. https://doi.org/10.4236/ajps.2015.67106

[36] Roy, P.K. and Yadav, J.P. (996) Effect of Combined Use of Organic Manures and Chemical Fertilisers on Growth and Productivity of Banana. Annals of Agricultural Research, 17, 366-369.

[37] Ochola, D., Ocimati, W., Tinzaara, W., Blomme, G. and Karamura, E. (2014) Interactive Effects of Fertiliser and Inoculum Concentration on Subsequent Development of Xanthomonas Wilt in Banana. African Journal of Agricultural Sciences, 9, 2727-2735. https://doi.org/10.5897/AJAR2014.8787

[38] Sharma, A., Kher, R., Wali, V.K. and Bakshi, P. (2009) Effect of Biofertilisers and Organic Manures on Physico-Chemical Characteristics and Soil Nutrient Composition of Guava (Psidium guajava L.) cv. Sardar. SKUAST Journal of Research, 8, 150 -156.

[39] Kayongo, S.N., Sebuliba, J.M. and Nyombi, K. (2015) Responses of East African Highland Bananas (EAHB-AAA) Cultivars to Drought Stress. Uganda Journal of Agricultural Sciences, 16, 55. https://doi.org/10.4314/ujas.v16i1.5 
[40] Demiss, M., Beyen, S. and Kidanu, S. (2019) Biomass Accumulation and Potassium Concentrations in Tissue of Teff (Eragrostis tef Zucc. Trotter) at Three Growth Stages in Vertisols and Nitisols of the Central Highlands of Ethiopia. African Journal of Agricultural Research, 14, 345-353.

[41] Dorel, M. and Besson, N. (1996) Organic Fertiliser Uses in Banana Growing. CIRAD FLHOR, Fort de France, 9:15. 